\title{
Pengaruh Kepuasan Wisatawan Terhadap Willingness to Pay Taman Wisata Alam Kawah Ijen
}

\author{
Esa Riandy Cardias ${ }^{1}$, Chafid Fandeli ${ }^{2}$
}

\author{
Affiliation \\ ${ }^{1}$ Magister Kajian Pariwisata, Universitas Gadjah Mada \\ 2 Magister Kajian Pariwisata, Universitas Gadjah Mada
}

\section{Correspondence}

Esa Riandy Cardias. Master Program of Tourism Studies Universitas Gadjah Mada. Email:cardias.esa@gmail.com

\begin{abstract}
Taman Wisata Alam Kawah Ijen (92 ha) is a part of Cagar Alam Kawah ljen (2.468 ha) where various rare biota is protected. UNESCO established Kawah ljen as one for Biosphere Reserve from 120 countries in the world (2016). All the uniqueness of TWAKI attracted many tourists to visit this destination and affected the environment capacity to be exceeded in the last 4 years. Therefore, proper destination management is needed, but in the effort to do it, a significant amount of funds is needed. Willingness to pay (WTP) from the tourist is expected as another source of funding outside the government. Set as the benchmark in measuring WTP is providing maximum satisfaction to tourists. This study aims to find the level of tourist satisfaction, the effect of tourist satisfaction on WTP, and the level of WTP. This research is quantitative research with Partial Least Square Path Modelling as the tool of measurement. The use of this method is to understand the measurement of correlational and causal from each variable and assess the significance of each hypothesis. The result of this research shown that: aspect of attractions, amenities, external accessibilities, internal accessibilities, human resources, and destination image reflect the tourist satisfaction; The tourist satisfaction based on attraction, human resource, and destination's image have positive and significant effect on WTP. Meanwhile, the tourist satisfaction based on amenities, external accessibilities, and internal accessibilities cannot give any effect on WTP; The average WTP is US\$2 28 from an international tourist and Rp 25.000 from domestic. Based on this number, the economic value from ecotourism and ticket revenue based on WTP is US\$ 864.528 and Rp 3.776.800.000.
\end{abstract}

Keyword: Nature Park; Ecotourism; Tourist Satisfaction; Willingness To pay; Partial Least Square Path Modelling

Article Information:

Submitted 28 Mei 2021|Revised 22 July 2021|Accepted 26 July 2021

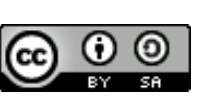

Copyright $(2021$ by the author(s). This article is published by Universitas Gadjah Mada, Indonesia under the Creative Commons Attribution (CC BY 4.0) license. Anyone may reproduce, distribute, translate, and create derivative works of this article (for both commercial and noncommercial purposes), subject to full attribution to the original publication and author(s). The full terms of this license may be seen at

http://creativecommons.org/licenses/by/4.0/legalcod 


\section{Pendahuluan}

TWAKI (92 ha) merupakan bagian dari kawasan Cagar Alam Kawah ljen (2.468 ha) dengan berbagai macam biota yang dilindungi. Pada tahun 2016 UNESCO menetapkan Cagar Alam Kawah Ijen sebagai salah satu dari 120 Cagar Biosfer di dunia dengan tampak alam berupa pegununggan dengan ketinggian $2.443 \mathrm{Mdpl}$ dan kawah danau dengan tingkat keasaman tertinggi di dunia serta fenomena api biru atau blue fire sebagai daya tarik utama mereka bagi wisatawan. Fenomena api biru di Kawah ljen sendiri berbeda dengan fenomena api biru di negara lain yang hanya bisa dilihat setelah meletusnya gunung berapi ataupun setelah terjadi kebakaran (Grunewald, 2008). Selain itu aktivitas para penambang belerang di destinasi ini sebagai salah satu bentuk atraksi kebudayaan juga turut menentukan keputusan wisatawan untuk berkunjung (Ichsani, 2014; Fitroh, dkk 2017).

Beragam upaya untuk menarik wisatawan ke TWAKI juga dilakukan pemerintah daerah dalam bentuk penyelenggarakan event-event bertajuk pariwisata yang dilaksanakan di destinasi ini setiap tahunya, seperti International Tour de ljen, Ijen Summer Jazz, dan Ijen Green Run. Selain itu, dari pihak BBKSDA Jawa Timur juga memaksimalkan pembangunan infrastruktur publik berupa pendopo dan toilet-toilet di jalur pendakian serta di puncak gunung guna memberikan fasilitas kepada wisatawan ketika berada di destinasi wisata.

Berbagai atraksi pariwisata yang dimiliki oleh TWAKI serta upaya-upaya yang telah dilakukan pemerintah tersebut berpengaruh pada tingkat kenaikan kunjungan wisatawan secara signifikan dari tahun 2014 sampai dengan 2018, yaitu sejumlah 95.717 (2014), 169.447 (2015), 202.730 (2016), 176.095 (2017) dan 181.858 (2018). Komposisi kunjungan wisatawan selalu didominasi oleh wisatawan nusantara selama tahun 2014 hingga 2018. Hanya pada tahun 2012 kunjungan wisatawan mancanegara lebih tinggi (55,3 persen) dibandingkan kunjungan wisatawan nusantara. Tingginya angka kunjungan wisatawan tersebut menjadikan TWAKI sebagai Taman Wisata Alam di Jawa Timur dengan kunjungan tertinggi pada tahun 2013 hingga 2018 (BBKSDA Jawa Timur, 2019).

Di satu sisi peningkatan jumlah kunjungan wisatawan menunjukkan popularitas TWAKI sebagai sebuah produk wisata (supply side). Di sisi lain hal ini menimbulkan kekhawatiran terkait berkurangnya kemampuan TWAKI dalam melaksanakan fungsi utamanya sebagai area pelestari alam. Merujuk pendapat Douglas (1975), bahwa areal hutan yang dikembangkan untuk wisata hanya dapat dikunjungi oleh lima orang wisatawan setiap hari per hektarnya (Fandeli, 2002). Dengan demikian luas 92 ha TWAKI hanya mampu menampung sebanyak 165.600 wisatawan setiap tahunnya. Berdasarkan perhitungan ini dapat disimpulkan bahwa daya dukung lingkungan TWAKI telah terlampaui dalam empat tahun terakhir.

Kedatangan wisatawan dalam jumlah besar dan terus adanya peningkatan jumlah wisatawan, menjadi suatu permasalahan yang perlu dikaji mendalam. Sejauh ini belum diketahui apakah yang mengunjungi TWAKI termasuk golongan ekowisatawan atau wisatawan masal. Keberadaan wisatawan di destinasi berstatus ekowisata secara kasat mata memang menjadikan status wisatawan sebagai ekowisatawan, tetapi belum tentu mereka sadar konservasi dan peduli pada masyarakat lokal.Tingginya angka kunjungan wisatawan menimbulkan beragam permasalahan 
yang justru dapat mengancam masa depan TWAKI seperti; banyaknya sampah plastik yang dihasilkan wisatawan menumpuk pada jalur pendakian dan tentunya kondisi tersebut akan berdampak buruk pada ekosistem hutan (Zen 2016); meningkatnya tindakan vandalisme di area destinasi (Pratami, 2017); serta dapat mengganggu siklus perkembangbiakan hewan serta mengubah perilaku alami mereka (Finnesey, 2015).

Diamati dari sudut pandang pasar wisata (demand side), jumlah wisatawan TWAKI yang mencapai ratusan orang pada hari biasa dan mencapai ribuan orang pada akhir pekan dapat membahayakan keselamatan wisatawan dikarenakan jalur pendakian yang curam dan sempit. Kondisi tersebut juga mampu menyebabkan terhambatnya proses evakuasi apabila terjadi peningkatan status gunung api maupun kejadian alam lainnya (Pratami, 2017). Kepadatan wisatawan di TWAKI juga menyebabkan ruang gerak mereka menjadi terbatas ketika berpapasan selama pendakian dan ketika berada dipuncak gunung, karena hingga saat ini pemanfaatan sumber daya TWAKI hanya terbatas pada area kawah saja (Pratami, 2017). Kepadatan tersebut mengakibatkan tingkat kenyamanan para wisatawanpun juga akan berkurang (Gunn, 1994 dalam Muhammad, 2013), dan pada akhirnya dapat berdampak pada penurunan kepuasan wisatawan terhadap destinasi ini. Kepuasan wisatawan tidak dapat diperoleh secara maksimal bila terjadi ketidakseimbangan antara areal yang dibutuhkan dengan jumlah wisatawan yang ada (Fandeli, 2002).

Untuk mengatasi over carrying capacity TWAKI pemanfaatan ruang/permintakatan dilakukan agar destinasi tetap bisa mengakomodir fungsi wisata dan tetap menjaga fungsi pokoknya sebagai kawasan pelestari alam (Widowati dan Nadra, 2013; Widiyanti, 2016; Aryasa, 2017). Permintakatan di TWA berupa area intensif/ruang wisata utama, area semi intensif/ruang penunjang dan area ekstensif/ruang konservasi (Amir, 2012; Beljai dkk, 2014). Dengan adanya permintakatan, maka pemanfaatan sumber daya alam dapat dikontrol secara efektif dan mengurangi lalu lintas kepadatan wisatawan menuju kawah.

Permintakatan membutuhkan biaya yang tidak sedikit, oleh karena itu dibutuhkan berbagai sumber pendanaan untuk melakukan upaya tersebut. Mengingat kemampuan negara untuk menjaga kawasan hutan konservasi sangat lemah karena alokasi anggaran tidak sebanding dengan luas hutan yang ada, sehingga anggaran untuk perlindungan pun masih sangat minim (Wonodipuro, 2018). Sumber pendanan untuk TWAKI tersebut tidak hanya berasal pemerintah, melainkan dapat juga berasal dari wisatawan yang berkunjung ke destinasi wisata tersebut. Hal ini merupakan upaya untuk memberikan manfaat edukasi dan membangun kepedulian (awareness) wisatawan terhadap nilai konservasi yang dapat diwujudkan dalam bentuk kontribusi kesediaan membayar atau willingness to pay (Dhaniswara, 2014; DFR 2016). Selain itu manfaat lainya yaitu agar wisatawan tetap dapat menikmati kegiatan wisata dengan dibebankan biaya yang bertujuan untuk pengelolaan destinasi wisata (Isnan, 2017).

Nilai willingness to pay akan semakin tinggi jika wisatawan merasa puas terhadap produk dan jasa yang diterimanya (Gall, 2009). Kepuasan wisatawan digunakan sebagai patokan dalam mengukur keinginan wisatawan untuk membayar peningkatan konservasi, jika kepuasan yang didapat lebih tinggi sehingga dapat mengarah pada keinginan yang lebih besar untuk membayar 
(Bigne et al., 2005). Sejalan dengan pendapat Sullivan dkk (1995) bahwa dalam pola hubungan pariwisata dengan ekologi yang berujung pada keberlanjutan mengindikasikan bahwa kepuasan wisatawan merupakan salah satu aspek penting dalam mempertemukan nilai ekologi pada profitabilitas. Oleh sebab itu penting dalam praktek pelaksanaan pariwisata untuk memperhatikan tingkat kepuasan wisatawan sebagai bentuk apresiasi terhadap willingness to pay mereka. Studi yang mengkaji hubungan kedua topik terkait kepuasan wisatawan dengan willingness to pay masih terbatas (Huang and Satchabut, 2016).

Dengan demikian perlu diadakan penelitian untuk mengkaji hubungan keduanya secara lebih lanjut. Peneliti memilih judul "Pengaruh Kepuasan Wisatawan Terhadap Willingness to Pay Ekowisata Taman Wisata Alam Kawah ljen" sebagai upaya untuk membuka khazanah baru terkait. Berdasarkan permasalahan pada ekowisata TWAKI maka dilakukan analisis yang bertujuan untuk: (1) menganalisis faktor-faktor kepuasan wisatawan TWAKI, (2) menganalisis pengaruh kepuasan wisatawan terhadap WTP TWAKI, dan (3) menganalisis tingkat dan besaran WTP wisatawan TWAKI.

\section{Metode}

\section{Metode Pengumpulan Data}

Penelitian dilakukan di Taman Wisata Alam Kawah ljen yang terletak di dua wilayah adminitratif yaitu Desa Tamansari Kecamatan Licin Kabupaten Banyuwangi dan Desa Sempol Kecamatan ljen Kabupaten Bondowoso.

Penentuan responden dilakukan secara sengaja. Responden adalah wisatawan yang sudah mengalami pengalaman ekowisata TWAKI. Responden wisatawan mancanegara berjumlah 15 orang dan wisatawan nusantara berjumlah 85 orang. Jumlah total responden 100 orang. Data diperoleh melalui berbagai teknik pengambilan data pada penelitian ini :

a) Observasi: pengambilan data dilakukan dengan cara pengamatan, kunjungan dan penilaian langsung terhadap kondisi sosial ekonomi di kawasan ekowisata.

b) Survei: pengambilan data dilakukan dengan pendekatan survei dengan daftar pertanyaan yang telah disiapkan. Bentuk pertanyaan bersifat tertutup, semi terbuka dan terbuka.

c) Studi pustaka: Bahan bacaan diperoleh dari hasil penelitian terdahulu, laporan dan dokumen berbagai instansi terkait topik penelitian, serta internet.

\section{Metode Analisis Partial Least Square}

Partial Least Square (PLS) merupakan analisis persamaan struktural (SEM) berbasis varian yang secara stimulant dapat melakukan pengujian model pengukuran sekaligus pengujian model struktural. Model pengukuran digunakan untuk uji validitas dan reliabilitas, sedangkan model struktural digunakan untuk uji kausalitas (pengujian hipotesis dengan model prediksi). Adapun nilai dari model pengukuran yang harus diperiksa pada hasil analisis PLS adalah Convergen validity (CV) melalui dua jenis ukuran yaitu average variance extracted (AVE) minimal sebesar 0,5 dan nilai composite reliability (CR) minimal sebesar 0,7 ; validitas diskriminan melalui nilai AVE harus lebih besar dari nilai laten lainya yang terbentuk, atau melalui nilai loading untuk masingmasing indikator diharapkan lebih tinggi dari cross loadingnya. Sementara dalam model 
struktural dilakukan uji kecocokan pada inner model berkaitan dengan pengujian hubungan antar variabel laten yang sebelumnya dihipotesiskan (Indahyanti,2013). Adapun hipotesis tersebut bisa diterima apabila nilai t-statistik lebih besar dibandingkan dengan nilai t-tabel yang sudah ditentukan pada pengujian pada alat yakni 1,96; selain itu nilai $\mathrm{p}$ yang dimiliki harus lebih kecil dari 0,05 (Kencana dan Mertha, 2014). Sehingga pertimbangan model konseptual penelitian yang melibatkan indikator formatif pada model persamaan struktural tersebut yang mendasari pemilihan metode analisis PLS.

Variabel yang diteliti adalah kepuasan wisatawan dan willingness to pay yang dioperasionalkan ke dalam dimensi indikator-indikator pembentuknya. Dimensi pertama yang menjadi penyebab dari kepuasan adalah kualitas destinasi wisata, yaitu meliputi persepsi wisatawan tentang atraksi wisata (keindahan bentang alam, variasi atraksi, otentisitas atraksi, kondisi adat dan budayanya, tempat yang memberikan pengetahuan/edukasi, dan kebersihan); amenitas (keragaman atau kelengkapan fasilitas penunjang, kondisi fisik sarana dan prasarana, kenyamanan ketika menggunakan sarana dan prasarana; aksesibilitas (ketersediaan tanda penunjuk arah menuju destinasi dan perangkat lainya, kemudahan mengakses dan frekuensi transportasi menuju destinasi, jarak tempuh, keadaan jalan yang dilalui ketika menuju atau selama di destinasi); sumber daya manusia (kemampuan pengelola memberikan pelayanan, daya tanggap pengelola dalam membantu wisatawan, pengelola mempunyai komunikasi yang baik dalam menjelaskan kepada wisatawan, kemampuan pengelola memberikan jaminan kamanan kepada wisatawan), citra destinasi (Branding ljen sebagai api biru yang hanya terdapat di dunia, keramahan masyarakat lokal, suasana destinasi yang kondusif), termasuk harga (kesesuaian memberikan harga dengan kualitas daya tarik wisata, jasa pramuwisata lokal, jasa makanan dan minuman dan penyediaan akomodasi). Pada akhirnya kepuasan yang didapat tersebut akan berpengaruh terhadap peingkatan willingness to pay (Gall, 2009) yaitu dalam bentuk kesediaan wisatawan membayar lebih tinggi meskipun produk lain bersaing memberi harga yang lebih murah; meskipun harga produk mengalami kenaikan; dan bersedia menambah waktu dari rencana awal untuk menambah pengalaman di tempat yang ditawarkan.

\section{Metode Analisis Willingness to Pay}

Willingness to pay adalah keinginan membayar seseorang terhadap barang dan jasa yang dihasilkan oleh sumberdaya alam dan lingkungan atau pengukuran nilai moneter barang dan jasa untuk nilai ekologis ekosistem atau lingkungan (Sadikin, 2017). Dugaan rataan WTP dihitung dengan rumus:

$$
E W T P=\sum_{i=0}^{n} W T P i P f i
$$

EWTP adalah dugaan rataan WTP, WTPi adalah nilai WTP ke-i, Pfi adalah frekuensi relatif, $\mathrm{n}$ adalah jumlah responden, dan i adalah responden ke-i yang bersedia membayar. Penjumlahan data adalah nilai tengah atau rataan WTP yang dikonversikan terhadap total populasi yang dimaksud. Setelah didapat dugaan nilai tengah atau rataan WTP (EWTP), maka dapat diduga nilai WTP secara total (TWTP) dengan rumus:

$$
T W T P=\sum_{i=0}^{n} W T P i\left(\frac{n i}{N}\right) P
$$


TWTP adalah total WTP, WTPi adalah WTP individu ke-i, ni adalah jumlah contoh ke-i yang bersedia membayar sebesar WTP, $\mathrm{N}$ adalah jumlah responden, $\mathrm{P}$ adalah jumlah populasi, $\mathrm{i}$ adalah responden ke-i yang bersedia membayar ekowisata atau jasa lingkungan.

\section{Hasil dan Pembahasan}

\section{Karakteristik Sosial Ekonomi Wisatawan}

Mayoritas responden mancanegara 78 persen berkunjung ke TWAKI satu kali setahun terakhir. Kecenderungan tersebut juga berlaku untuk wisatawan nusantara. Sebanyak 47,6 persen mengunjungi TWAKI hanya satu kali dalam satu tahun terakhir, sisanya 22,2 persen berkunjung dua tahun sekali. Responden mancanegara terdiri dari wisatawan berkebangsaan Jerman, Usa, Australia, Prancis, Italia, India, Rusia, Malaysia dan Swedia. Sementara untuk wisatawan nusantara sebagian besar berasal dari Bali, Manado, Jawa Timur (Probolinggo, Surabaya, Malang), Kalimantan, Bekasi, Jakarta, Bogor, Bandung, Yogyakarta dan Lombok. Berikut profil responden ditinjau dari beberapa indikator yang ditampilkan pada Tabel 1.

Tabel 1 Profil Responden

\begin{tabular}{|c|c|c|c|c|c|c|}
\hline \multirow[b]{2}{*}{ Karakteristik } & \multicolumn{3}{|c|}{ Wisatawan Mancanegara } & \multicolumn{3}{|c|}{ Wisatawan Nusantara } \\
\hline & Kategori & Jumlah & $\%$ & Kategori & Jumlah & $\%$ \\
\hline \multirow[b]{5}{*}{ Umur } & $17-19$ & 2 & 13,3 & & 13 & 15,3 \\
\hline & $20-29$ & 11 & 73,3 & & 52 & 61,2 \\
\hline & $30-39$ & 2 & 13,3 & & 14 & 16,5 \\
\hline & $40-49$ & & & & 6 & 7,1 \\
\hline & $>50$ & & & & & \\
\hline \multirow[b]{2}{*}{ Jenis Kelamin } & Laki-laki & 6 & 40,0 & & 31 & 36,5 \\
\hline & Perempuan & 9 & 60,0 & & 54 & 63,5 \\
\hline \multirow[b]{7}{*}{ Pendidikan } & SD & & & & & \\
\hline & SMP & & & & 2 & 2,4 \\
\hline & SMA & 1 & 6,7 & & 27 & 31,8 \\
\hline & Diploma & 3 & 20,0 & & 8 & 9,4 \\
\hline & Sarjana & 5 & 33,3 & & 43 & 50,6 \\
\hline & Magister & 5 & 33,3 & & 5 & 5,9 \\
\hline & Doktor & 1 & 6,7 & & 0 & \\
\hline \multirow{8}{*}{ Pekerjaan } & Mahasiswa & 4 & 26,7 & & 14 & 16,5 \\
\hline & PNS & 3 & 20 & & 6 & 7,1 \\
\hline & TNI/Polisi & & & & 3 & 3,5 \\
\hline & Manajer/Direktur & & & & 1 & 1,2 \\
\hline & Wirausaha & & & & 16 & 18,8 \\
\hline & Pensiunan & & & & & \\
\hline & Pegawai swasta & 7 & 46,7 & & 41 & 48,2 \\
\hline & Lainnya & 1 & 6,7 & & 4 & 4,7 \\
\hline \multirow{4}{*}{ Pendapatan } & $<29999$ & 6 & 40 & $<1$ juta & 9 & 10,6 \\
\hline & $30000-49999$ & 4 & 26,7 & 1-3 Juta & 33 & 38,8 \\
\hline & $50000-79999$ & 1 & 6,7 & 4-6 juta & 20 & 23,5 \\
\hline & $80000-99999$ & & & 7-9 juta & 3 & 3,5 \\
\hline
\end{tabular}




\begin{tabular}{|c|c|c|c|c|c|c|}
\hline & \multicolumn{3}{|l|}{$>100000$} & $>9$ juta & \multirow[t]{2}{*}{6} & \multirow[t]{2}{*}{7,1} \\
\hline & tidak & & & tidak & & \\
\hline & berpenghasilan & 4 & 26,7 & berpenghasilan & 14 & 16,5 \\
\hline \multirow{5}{*}{ Tanggungan } & $1-2$ & 8 & 53,3 & & 50 & 58,8 \\
\hline & $3-4$ & 3 & 20,0 & & 14 & 16,5 \\
\hline & $5-6$ & & & & 7 & 8,2 \\
\hline & $>7$ & & & & & \\
\hline & Belum ada & 4 & 26,7 & & 14 & 16,5 \\
\hline$n$ & & 15 & 100 & & 85 & 100 \\
\hline
\end{tabular}

Sumber : Data Diolah (2020)

Usia wisatawan didominasi oleh mereka yang berusia produktif berkirar 20-29 tahun. Angka ini sejalan dengan latar belakang pendidikan wisatawan yang sebagian besar merupakan lulusan perguruan tinggi. Dapat digambarkan bahwa kondisi alam TWAKI membutuhkan orang-orang yang memiliki kekuatan fisik cukup baik dimana mereka didominasi oleh usia yang cenderung masih produktif. Realita empiris ini juga menjelaskan bahwa, wisata alam minat khusus seperti TWAKI masih didominasi oleh wisatawan berpendidikan tinggi. Pekerjaan mereka yang didominasi oleh pegawai swasta baik wisatawan mancanegara dan wisatawan nusantara mengindikasikan bahwa waktu luang yang dimiliki pegawai swasta dihabiskan untuk menikmati wisata alam minat khusus dibandingkan dengan pegawai negeri. Rata-rata pendapatan yang dihasilkan berkisar antara 1-3 juta untuk wisatawan nusantara dan dibawah US\$30,000 per tahun untuk wisatawan mancanegara, dengan jumlah tanggungan keluarga 1-2 orang. Artinya TWAKI masih bisa dijangkau oleh berbagai kalangan dengan rentang pendapatan yang tidak terlalu besar sekalipun.

\section{Hasil Analisis Partial Least Square}

Kepuasan wisatawan merupakan ukuran keseluruhan dari persepsi wisatawan pada setiap kualitas destinasi (Prayag, 2008 dalam Setyanto dan Pangestuti, 2019). Ukuran tersebut dapat dipertimbangkan sebagai nilai mengenai kualitas dari destinasi pariwisata, misalnya perlakuan dan pelayanan yang dirasakan wisatawan selama mengunjungi tempat wisata. Adapun hubungan reflektif hasil persepsi kepuasan wisatawan di TWAKI terefleksikan melalui komponenkomponen destinasi wisata seperti atraksi wisata, amenitas, aksesibilitas, sumber daya manusia, dan citra destinasi TWAKI.

Berdasarkan aspek atraksi wisata, kepuasan paling tinggi terefleksikan pada item ketika wisatawan menyaksikan api biru, sementara item informasi edukasi yang didapatkan selama berkunjung di TWAKI memiliki terendah. Pada aspek amenitas, kepuasan wisatawan paling tinggi terdapat pada item kemudahan wisatawan mendapatkan akomodasi dan kepuasan terendah terkait dengan kebersihan toilet. Persepsi wisatawan merasa nyaman dalam melakukan pendakian merupakan bentuk refleksi dari kepuasan aksesibilitas internal paling tinggi, sementara nilai terendah terletak pada kepuasan wisatawan terhadap kondisi jalur pendakian. Pada aspek aksesibilitas eksternal, kepuasan wisatawan tertinggi melalui ketersediaan 
transportasi dan kondisi jalan yang baik menuju destinasi, dan keamanan jalan akses menuju destinasi memiliki nilai kepuasan terendah. Kepuasan wisatawan tertinggi berdasarkan aspek SDM terletak pada faktor keramahan pengelola, sementara kepuasan terendah pada faktor pelayanan pemandu wisata. Kepuasan wisatawan terhadap citra TWAKI sebagai destinasi api biru satu-satunya di dunia merupakan kepuasan tertinggi dari aspek citra destinasi, dan kepuasan terendah pada kondusifitas TWAKI.

Pada hubungan formatif nilai-nilai koefisien jalur menunjukan pengaruh langsung (direct effect) antara laten eksogenus dengan laten endogenus ditunjukan pada Gambar 1 berikut.

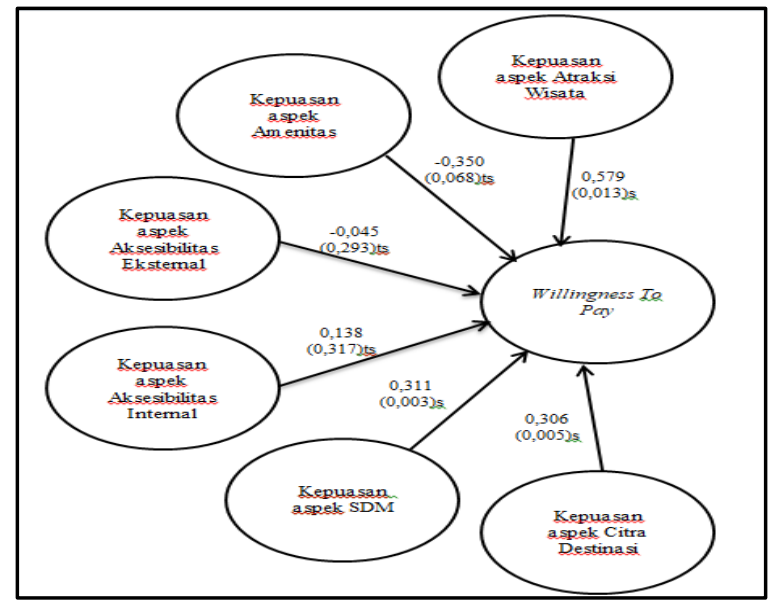

Gambar 1 Hasil Analisis Model Struktural Penelitian Sumber: Data diolah, 2020

Hasil penelitian formatif menunjukkan bahwa terdapat tiga faktor kepuasan yang mempengaruhi WTP yaitu faktor kepuasan berdasarkan aspek atraksi wisata, sumber daya manusia, dan citra destinasi. Hal tersebut menunjukan adanya korelasi positif dengan WTP, yaitu semakin berkualitas indikator-indikator dalam faktor atraksi wisata (bentang alam, atraksi budaya, aktivitas, fungsi destinasi dan harga) maka wisatawan akan semakin bersedia membayar tinggi. Semakin intensif wisatawan memperoleh informasi serta berinteraksi secara intim dengan pengelola/karyawan, kesediaan membayar wisatawan juga akan meningkat. Semakin terjaga citra api biru dan keamanan ljen, serta interaksi dengan masyarakat lokal yang semakin intim juga mampu membuat wisatawan semakin bersedia membayar.

Ketiga faktor lainya adalah faktor kepuasan wisatawan berdasarkan aspek amenitas, aksesibilitas eksternal, dan aksesibilitas internal masing-masing memiliki koefisien jalur sebesar -0,350; 0,045; dan 0,138. Hal ini menunjukan bahwa melalui refleksi ketiga aspek tersebut ternyata belum mampu memberikan pengaruh yang signifikan terhadap WTP. Walaupun ketiga faktor kepuasan tersebut tidak berpengaruh terhadap WTP, perlu dilakukan peningkatan pelayanan baik mutu maupun kuantitas yang tetap berpegang pada konservasi dan keberlanjutan di 
destinasi TWAKI. Hal tersebut akan berakibat pada peningkatan kepuasan wisatawan sehingga akan mendorong kunjungan ulang.

\section{Hasil Analisis Willingness To Pay}

Sebelum mewawancarai wisatawan untuk mengidentifikasi nilai WTP maka ditentukan terlebih dahulu nilai dasar WTP yang akan dijadikan standar nilai WTP dalam analisa ini. Saat ini harga tiket masuk TWAKI adalah Rp.5000- Rp.7500 untuk wisatawan nusantara dan Rp.100.000Rp.150.000 untuk wisatawan mancanegara, yaitu sebesar 20 kali lipat harga tiket masuk wisatawan nusantara. Penentuan nilai dasar WTP dihitung berdasarkan data jumlah wisatawan pada tahun 2018, yaitu wisatawan nusantara berjumlah 151.072 orang dan wisatawan mancanegara berjumlah 30.876 orang (Tabel 1.1). Kemudian melihat pada total anggaran yang dibutuhkan oleh TWAKI pada tahun 2018 untuk biaya pemeliharaan, pengelolaan dan konservasi yaitu Rp.7.002.088.600 (BBKSDA Seksi Konservasi Wilayah V Jawa Timur, 2019). Semua data ini lalu dihitung nilai dasar WTP dari jumlah total anggaran dibagi jumlah pengunjung wisatawan lokal dan mancanegara, yaitu 7.002.088.600 dibagi 181.858. Sehingga mendapatkan konversi nilai dasar WTP wisatawan nusantara yaitu 7.002.088.600 / ((30.876 x 20 kali harga tiket wisatawan nusantara) + 151.072) dan menghasilkan angka Rp 9.131,66 atau dibulatkan menjadi Rp.10.000 sebagai nilai dasar WTP untuk wisatawan lokal. Untuk nilai dasar WTP wisatawan mancanegara adalah 9.131,66 dikalikan 20 dan menghasilkan angka 182.633,324, kemudian dibulatkan menjadi Rp.182.633 atau dengan nilai kurs saat survei dilakukan yaitu Rp.14.000 menjadi US \$13.045237 yang dibulatkan menjadi US \$14.

Hasil wawancara mengungkapkan bahwa responden wisatawan mancanegara yang bersedia membayar ada 100 persen dan 72 persen wisatawan nusantara. Nilai WTP dihitung berdasarkan data distribusi WTP responden TWAKI pada Tabel 2 berikut. Penghitungan berapa kali nilai tertentu muncul dibadingkan dengan jumlah data seluruhnya.

Tabel 2 Distribusi Nilai WTP Wisatawan TWAKI

\begin{tabular}{|c|c|c|c|c|c|c|c|}
\hline \multicolumn{4}{|c|}{ Wisatawan Nusantara } & \multicolumn{4}{|c|}{ Wisatawan Mancanegara } \\
\hline $\begin{array}{l}\text { Nilai } \\
\text { WTP(Rp) }\end{array}$ & $\begin{array}{l}\text { Frekuensi } \\
\text { (Wisatawan) }\end{array}$ & $\begin{array}{l}\text { Frekuensi } \\
\text { Relatif }\end{array}$ & $\begin{array}{l}\text { Jumlah } \\
\text { (Rp) }\end{array}$ & $\begin{array}{l}\text { Nilai } \\
\text { WTP(US\$) }\end{array}$ & $\begin{array}{l}\text { Frekuensi } \\
\text { (Wisatawan) }\end{array}$ & $\begin{array}{l}\text { Frekuensi } \\
\text { Relatif }\end{array}$ & $\begin{array}{l}\text { Jumlah } \\
\text { (US\$) }\end{array}$ \\
\hline 100000 & 1 & 0,02 & 1639,3 & 100 & 0 & 0 & 0 \\
\hline 60000 & 1 & 0,02 & 983,6 & 75 & 0 & 0 & 0 \\
\hline 50000 & 2 & 0,03 & 1639,3 & 70 & 0 & 0 & 0 \\
\hline 45000 & 3 & 0,05 & 2213,1 & 60 & 1 & 0,07 & 4 \\
\hline 40000 & 2 & 0,03 & 1311,5 & 50 & 2 & 0,13 & 6,7 \\
\hline 35000 & 4 & 0,07 & 2295,1 & 35 & 1 & 0,07 & 2,3 \\
\hline 30000 & 8 & 0,13 & 3934,4 & 30 & 1 & 0,07 & 2 \\
\hline 25000 & 11 & 0,18 & 4508,2 & 25 & 3 & 0,2 & 5 \\
\hline 20000 & 12 & 0,19 & 3934,4 & 20 & 5 & 0,3 & 6,7 \\
\hline 15000 & 6 & 0,1 & 1475,4 & 14 & 1 & 0,07 & 0,9 \\
\hline 10000 & 8 & 0,13 & 1311,5 & 10 & 1 & 0,07 & 0,7 \\
\hline
\end{tabular}




\begin{tabular}{rrrrrrrr}
\hline 5000 & 3 & 0,05 & 245,9 & & & & \\
\hline $\mathrm{n}$ & 61 & 1 & 25491,8 & $\mathrm{n}$ & 15 & 1 & 28,2667 \\
\hline
\end{tabular}

Sumber: Data Diolah (2020)

Nilai frekuensi pada tabel menunjukan jumlah wisawatan yang memilih nominal rupiah sesuai dengan kesediaan membayar masing-masing wisatawan, sementara nilai frekuensi relatif menunjukan perbandingan frekuensi wisatawan yang memilih nominal kesediaan membayar dan total wisatawan yang bersedia membayar. Adapun nilai rataan WTP wisatawan nusantara sebesar 25.491,8 atau dibulatkan Rp.25.000. Jumlah wisatawan nusantara TWAKI pada tahun 2018 adalah 151.072 orang, maka nilai ekonomi lingkungan ekowisata atau perkiraan pendapatan dari penjualan tiket adalah Rp.3.776.800.000. Sementara nilai rataan WTP wisatawan mancanegara sebesar US\$28,3 (dibulatkan US\$28). Jumlah wisatawan mancanegara TWAKI tahun 2018 adalah 30.876 orang, maka nilai ekonomi ekowisata dan perkiraan pendapatan dari penjualan tiket berdasarkan nilai WTP adalah US\$ 864.528 atau sekitar 12 milyar.

Berdasarkan hasil nilai rataan WTP responden wisatawan nusantara Rp.25.000 dan wisatawan mancanegara US \$28. Kedua nilai tersebut lebih besar dari nilai dasar WTP yang dihitung berdasarkan data jumlah wisatawan pada tahun 2018 dan lebih besar juga dari total anggaran yang dibutuhkan oleh TWAKI pada tahun 2018 untuk biaya pemeliharaan, pengelolaan dan konservasi. Nilai ini memperlihatkan kedua jenis preferensi wisatawan terhadap ekowisata TWAKI baik, sekaligus menunjukkan kepuasan wisatawan yang telah memanfaatkan sumber daya alam (lasha et al. 2015 dalam Sadikin, 2017) dan kepeduliaan terhadap lingkungan ekowisata agar lebih baik.

\section{Kesimpulan}

Bertitik tolak pada rumusan permasalahan, kajian-kajian teoritis serta hasil analisa yang dilakukan secara kuantitatif, dapat disimpulkan beberapa hal sebagai berikut:

1. Aspek atraksi, amenitas, aksesibilitas eksternal, aksesibilitas internal, sumber daya manusia, dan citra destinasi terbukti mampu merefleksikan kepuasan wisatawan di TWAKI. Kepuasan wisatawan berdasarkan aspek atraksi lebih mendominasi dibandingkan ke lima aspek lainya.

2. Kepuasan wisatawan berdasarkan aspek atraksi wisata, sumber daya manusia, dan citra destinasi memiliki nilai pengaruh positif dan signifikan terhadap WTP. Hal tersebut menunjukan adanya hubungan searah antara variabel eksogenous dan variabel endogenus. Berarti semakin tinggi nilai kepuasan wisatawan dari ketiga aspek tersebut WTP wisatawan juga akan meningkat. Namun pemeriksaan lebih dalam terhadap hubungan tersebut, ternyata pada kepuasan yang kurang maksimal dari pelayanan pemandu lokal membuat wisatawan juga bersedia membayar.

3. Kepuasan wisatawan berdasarkan aspek amenitas, aksesibilitas eksternal, dan aksesibilitas internal belum mampu memberikan pengaruh yang signifikan terhadap WTP. Ada sejumlah fakta yang pengelola belum lakukan sehingga mempengaruhi kepuasan wisatawan dan pada akhirnya juga berpengaruh pada nilai WTP, antara lain: tingkat kebersihan toilet yang buruk, minimnya himbauan kepada wisatawan mengenai potensi bahaya dan peralatan 
keselamatan yang diperlukan untuk melakukan pendakian, serta minimnya pagar pembatas jalan pada jalan yang berpotensi bahaya.

4. Sebanyak 100 persen wisatawan mancanegara dan 72 persen wisatawan nusantara bersedia membayar lebih atas kepuasan yang telah didapat selama di TWAKI. Nilai rataan WTP wisatawan mancanegara US\$ 28 dan Rp.25.000 wisatawan nusantara, sehingga masingmasing nilai ekonomi ekowisata dan perkiraan pendapatan dari penjualan tiket berdasarkan nilai WTP adalah US\$ 864.528 atau sekitar 12 milyar dan Rp.3.776.800.000. Kedua nilai tersebut menunjukan nilai lebih besar dari nilai dasar WTP yang dihitung berdasarkan data jumlah wisatawan pada tahun 2018. Total nilai tersebut juga lebih besar dari total anggaran yang dibutuhkan oleh TWAKI pada tahun 2018 untuk biaya pemeliharaan, pengelolaan dan konservasi.

\section{Saran}

Saran Penelitian lanjutan dapat mengadopsi model ini dengan menggunakan variable-variabel lain pengukur kepuasan wisatawan, dan metode analisis lain untuk mengukur nilai Willingness To Pay.

\section{Daftar Pustaka}

Amir, S. (2012). Optimasi Pemanfaatan Wisata Bahari Bagi Pengelolaan Pulau-Pulau Kecil Berbasis Mitigasi (Kasus Kawasan Gili Indah Kabupaten Lombok Utara Provinsi Nusa Tenggara Barat). Institut Pertanian Bogor.

Aryasa, A.M. (2017). Pengembangan Pengelolaan Kawasan Konservasi Dalam Taman Wisata Alam Telaga Warna-Telaga Pengilon Kabupaten Wonosobo. Tesis, Program Studi Magister Ilmu Lingkungan, Universitas Diponegoro.

Beljai, M., Muntasib, H., \& Sulistyantara, B. (2014). Konsep Penataan Lanskap Untuk Wisata Alam di Kawasan Taman Wisata Alam Sorong. Jurnal Manusia dan Lingkungan, 21(3), 356-365.

Dhaniswara, M. (2014). Analisis Willingness To Pay Menuju Pelestarian Ekosistem Wisata Bahari Karimunjawa Jawa Tengah. Fakultas Ekonomi dan Bisnis Universitas Diponegoro.

Demirgunes, B.K. (2015). Relative Importance of Perceived Value, Satisfaction and Perceived Risk on Willingness To Pay More. International Review of Management Marketing Econjournals, 5(4), 211-220.

Fandeli, C. (2000). Pengembangan Ekowisata Berbasis Konservasi di Taman Nasional. Fakultas Kehutanan UGM, Pusat Studi Pariwisata UGM, dan Kantor Kementerian Lingkungan Hidup Republik Indonesia.

Fandeli, C. (2002). Perencanaan Kepariwisataan Alam. Fakultas Kehutanan Universitas Gadjah Mada: Yogyakarta.

Fitroh, S.K.A., Hamid, D., \& Hakim, L. (2017). Pengaruh Atraksi Wisata dan Motivasi Wisatawan Terhadap Keputusan Berkunjung (Survei Pada Pengunjung Wisata Alam Kawah ljen). Jurnal Administrasi Bisnis, 42(2), 20-31.

Gall, E.M.L. (2009). Definition, Measurement and Determinant of The Consumer's Willingness to Pay: A Critical Synthesis and Directions for Further Research. Recherche et Applications en Marketing 24, 91-113.

Grunewald, O. (2008) Kawah Ijen Vulcano Indonesia. www.olivergrunewald.com 
Huang, Q.M., \& Satchabut, T. (2016). Factors Affecting Foreign Tourist's Satisfaction and Willingness To Pay More for Visiting Bangkok. School of Business, University of the Thai Chamber of Commerce.

Ichsani, I.Y. (2014). Place Brand Experience Wisatawan Kawah Ijen Terkait City Branding The Sun Rise of Java Kabupaten Banyuwangi.IImu Komunikasi-Fakultas IImu Sosial dan Ilmu Politik, Universitas Brawijaya.

Indahyanti, U. (2013). PPS-PLS. diakses pada Juni 2019.

Isnan, W. (2007). Kesediaan Membayar Pengunjung sebagai Dasar Pengelolaan Pariwisata Berkelanjutan. Balai Litbang Lingkungan Hidup dan Kehutanan Makassar, EBONI 14(2), 111-121.

Kencana, I.P.E.N., \& Mertha, I.W. (2014). People Participation as Sosial Capital for Realizing Sustainable Ecotourism. International Journal of Social, Management, Economics and Business Engineering, 8(10), 3014-3020.

Muhamad. (2013). Kapasitas Daya Dukung Fisik dan Lingkungan Optimal Sebagai Daya Dukung Kepariwisataan Alam Yogyakarta Utara setelah Pascaerupsi merapi 2010. Jurnal Kawistara, 3(2), 117-226.

Pratami, R.H.Y. (2017). Pengembangan Wisata Alam di Taman Wisata Alam Kawah Ijen. Fakultas Kehutanan, Institut Pertanian Bogor.

Sadikin, P.N., Mulatsih, S. \& Pramudya, B.. (2017). Analisis Willingness To Pay Pada Ekowisata Taman Nasional Gunung Rinjani. Jurnal Analisis Kebijakan Kehutanan, 14(1), 31-46.

Setyanto, E., \& Pangestuti, E. (2019). Pengaruh Komponen Destinasi Wisata Terhadap Kepuasan Pengunjung Pantai Gemah Tulungagung. Universitas Brawaijaya

Sullivan, K., De Silva, L., White, A.T., \& Wijeratne, M. (1995). Environmental Guideline for Coastal Tourism Development in Sri Lanka. University of Rhode Island and Coast Conservation Department, Sri Lanka.

Widiyanti, H. (2016). Strategi Tata Kelola Pengembangan Ekowisata di Taman Wisata Alam Kawah Ijen Provinsi Jawa Timur. Sekolah Pascasarjana, Institut pertanian Bogor.

Widowati, S., \& Nadra, N.M. (2013). Evaluasi Penerapan Prinsip-Prinsip dan Kriteria Ekowisata di Kawasan Taman Wisata Alam Kawah Ijen Banyuwangi. Jurnal Sosial dan Humaniora, 3(3), 312-321.

Wijayanto, T. (2017). Kementerian Lingkungan Hidup dan Kehutanan Lengkapi Infrastruktur Penunjang di Gunung ljen. kompas.com diakses pada 15 Februari 2018.

Wirajaya, Y. (2013). Analisis Kepuasan Wisatawan Mancanegara Terhadap Kualitas Pelayanan Pariwisata. Jurnal Manajemen dan Akuntansi, 2(3), 95-109.

Wonodipuro. (2018). Mahalnya Menjaga Indonesia. www.antarariau.com diakses pada 15 Februari 2018.

Zen, M.H., Wulandari, D. (2016). Pengembangan Wisata Alam di Taman Wisata Alam Kawah Ijen Studi Kasus Taman Wisata Alam Kawah Ijen. IOSR Jurnal Bisnis dan Manajemen, 18(8), 4147. 


\section{PROFIL PENULIS}

Esa Riandy Cardias, S. Par., M.Sc. Lahir di Banyuwangi, 18 Januari 1994. Menyelesaikan program sarjana di bidang Pariwisata pada tahun 2016 di Politeknik Negeri Pariwisata Bali. Kemudian melanjutkan studi S2 Kajian Pariwisata di Universitas Gadjah Mada lulus tahun 2020. Sejak tahun 2020 akhir, penulis menjalankan tugas sebagai Dosen Politeknik Negeri Banyuwangi mengampu mata kuliah manajemen obyek dan daya tarik wisata.

Prof. Dr. Ir. Chafid Fandeli, MS. Lahir di Kudus, 25 July, 1944. Meraih gelar Doktor pada bidang Ilmu Lingkungan di Universitas Gadjah Mada pada tahun 2000. la menyelesaikan pendidikan jenjang pascasarjana S2 di Program Magister Konservasi Sumberdaya Hutan di Universitas Gadjah Mada pada tahun 1985 dan program Sarjana dari jurusan Fakultas Kehutanan tahun 1973. Saat ini ia merupakan dosen pengampu pada Program Sarjana Kelas Internasional Institut Teknologi Yogyakarta, pascasarjana Institut Teknologi Yogyakarta, pascasarjana Kehutanan Universitas Gadjah Mada, Pascasarjana Geografi Universitas Gadjah Mada, Sekolah Pascasarjana Universitas Gadjah Mada, dan Pascasarjana Universitas Sebelas Maret. Untuk jabatan akademik ia menjabat sebagai Rektor Institut Teknologi Yogyakarta, Kepala Penasihat Pusat Studi Pariwisata Universitas Gadjah Mada serta Peneliti Senior Institut Teknologi Yogyakarta dan Universitas Gadjah Mada. 